\title{
Accumulation of heavy metals (cadmium and hexavalent chromium) in accessions of Hordeum Vulgare
}

\author{
Neha Mittal ${ }^{1}$, A.K. Srivastava ${ }^{1}$, Bhupendra ${ }^{2}$ and Kiran $^{3}$ \\ ${ }^{1}$ Department of Botany, C.C.S. University, Meerut, India \\ ${ }^{2}$ Department of Botany, Bundelkhand University, Jhansi, India \\ ${ }^{3}$ Institute of Environment \& Development Studies, Bundelkhand University, Jhansi, India
}

\begin{abstract}
Five partially tolerant and five non tolerant accessions of barley for cadmium and hexavalent chromium were analyzed for the assessment of heavy metal in the plant. This study was designed to assess total contents of $\mathrm{Cd}$ and $\mathrm{Cr}^{6+}$ in the plant root and leaves. The accumulation of metals from roots to shoots was evaluated in terms of Translocation Factor (TF). Total metal concentrations of $\mathrm{Cd}$ and $\mathrm{Cr}^{6+}$ in root and leaves varied between $29.84-0.35 \mu \mathrm{g} / \mathrm{g}^{-1}$.
\end{abstract}

Keywords: Heavy metals, Phytoremediation, Translocation factor, Barley.

\section{Introduction}

Contamination of soil and water with heavy metals has become a potential threat. Phytoremediation is one of the promising methods for reclamation of soils contaminated with toxic metals by using hyper accumulator plants (Baker et al., 2000; Ghosh \& Singh, 2005; La'zaro et al., 2006). Phytoremediation technologies using green plants to remove heavy metals from soil and water are now being identified as promising and non-destructive methods (Haferburg and Kothe 2010). More than 400 plant species belonging to 45 plant families have been identified and reported from temperate to tropical regions with the ability to tolerate and hyper accumulate trace elements (Baker \& Brooks, 1989). Accumulation of selected metals varied greatly among plants species and uptake of an element by a plant is primarily dependent on the plant species, its inherent controls, and the soil quality (Chunilall et al., 2005). Plants can tolerate high heavy metals concentration from soil by two basic strategies (Baker, 1981). The first strategy is called accumulation strategy where metal can accumulate in plants at both high and low concentration from soil (McGrath et al., 2001). These plants are capable of rendering the metals in various ways, for instance by binding them to cell walls, compartmentalizing them in vacuoles or complexing them to certain organic acids or proteins (Reeves and Baker, 2000). The second strategy is called exclusion strategy, where transport of heavy metals in shoots and leaves is limited over a wide range of metal concentrations in soil. Cadmium is a widespread heavy metal released into the environment by heating systems, metal working industries, waste incineration and contaminant of phosphates fertilizers. Chromium $(\mathrm{Cr})$ which has several roles in our daily life exists in various oxidation states of $\mathrm{Cr}^{6+}$ is highly toxic. However, a polluted area is contaminated with several heavy metals at a time. Therefore, the present experiment was designed for the evaluation of the accumulation of two heavy metals in agriculturally important crop barley.

\section{Materials and methods}

Cadmium chloride $\left(\mathrm{CdCl}_{2}\right)$ and sodium dichromate $\left(\mathrm{Na}_{2} \mathrm{Cr}_{2} \mathrm{O}_{7}\right)$ were used as sources of $\mathrm{Cd}^{2+}$ and $\mathrm{Cr}^{6+}$ respectively. Treatment with $10^{-3} \mathrm{M}$ of $\mathrm{Cd}^{2+}+\mathrm{Cr}^{6+}$ solution was given to partially tolerant and non tolerant* accessions of barley (Table 1).

Table 1. Partially tolerant and non tolerant* accessions of barley.

\begin{tabular}{|l|l|l|l|}
\hline Partially-tolerant & \multicolumn{2}{|c|}{ Non-tolerant } \\
\hline Lab Code & Accession & Lab Code & Accession \\
\hline B-16 & D.L.35 & B-60 & K-232 \\
B-35 & K-170 & B-79 & RD-915 \\
B-95 & IC.108128 & B-93 & IC.108124 \\
B-131 & IC.138925 & B-115 & IC.118664 \\
B-166 & K-125 & B-143 & IC.138950 \\
\hline
\end{tabular}

For estimating the accumulation of cadmium and hexavalent chromium in barley, roots and mature leaves sample were collected from the plants, grown hydroponically in $10^{-3} \mathrm{MCd}+\mathrm{Cr}$ solution. The samples were collected after eight days of culture. Oven dried $100 \mathrm{mg}$ roots and leaves were digested in $5 \mathrm{ml}$ of 1:1 
concentrated $\mathrm{HNO}_{3}$ and perchloric acid $\left(\mathrm{HClO}_{4}\right)$ till the whole material got digested and liquid content evaporated. The resultant digested matter was dissolved in $10 \mathrm{ml}$ of double glass-distilled water. Hexavalent chromium and cadmium accumulation were worked out in mature root and leaf samples of five accessions each of partially tolerant (PT) and non-tolerant (NT), using Atomic Absorption Spectrometer (A7000, LAB INDIA). Ratio of shoot to root accumulation were calculated using following formula,

$$
\mathrm{S} / \mathrm{R}=\quad \begin{gathered}
\text { Conc. of heavy metal in mature leaves } \\
\text { Conc. of heavy metal in root }
\end{gathered}
$$

\section{Results}

Cadmium and hexavalent chromium accumulation were worked out in mature root and leaf samples of five accessions of partially tolerant (PT) and non-tolerant (NT) of barley, using atomic absorption spectrophotometer (AAS). The concentration of hexavalent chromium and cadmium in shoot and root of barley are shown in table $2 \& 3$ and figure $1 \& 2$.

\begin{tabular}{|c|c|c|c|c|c|}
\hline \multirow[b]{3}{*}{ Acc. } & \multicolumn{5}{|c|}{ Hexavalent Chromium } \\
\hline & \multirow{2}{*}{$\begin{array}{l}\text { Roots } \\
\text { Con. }(\mu \mathrm{g} / \mathrm{gm})\end{array}$} & \multirow[b]{2}{*}{$\%$ RSD } & \multicolumn{2}{|l|}{ Mature Leaves } & \multirow[b]{2}{*}{$\mathrm{S} / \mathrm{R}$} \\
\hline & & & Con. $(\mu \mathrm{g} / \mathrm{gm})$ & $\%$ RSD & \\
\hline B-16(PT) & 7.60 & 22.44 & 4.26 & 6.89 & 0.56 \\
\hline $\mathrm{B}-35(\mathrm{PT})$ & 12.54 & 6.89 & 13.69 & 11.74 & 1.09 \\
\hline B-95(PT) & 11.39 & 2.13 & 6.56 & 4.78 & 0.58 \\
\hline $\mathrm{B}-131(\mathrm{PT})$ & 4.37 & 25.07 & 6.10 & 20.00 & 1.39 \\
\hline B-166(PT) & 15.19 & 9.12 & 4.49 & $\mathrm{HIGH}$ & 0.30 \\
\hline B-60(NT) & 10.47 & 15.93 & 3.37 & 23.30 & 0.32 \\
\hline B-79(NT) & 0.35 & 30.83 & -0.58 & -128.85 & -1.67 \\
\hline B-93(NT) & 14.27 & 13.81 & 4.26 & 6.89 & 0.30 \\
\hline B-115(NT) & 15.08 & 11.89 & 14.85 & 30.34 & 0.98 \\
\hline B-143(NT) & 13.81 & 16.91 & 2.88 & HIGH & 0.21 \\
\hline
\end{tabular}

Table 2. Accumulation ( $\mu \mathrm{g} \mathrm{g}^{-1}$ dry weight) of hexavalent chromium in roots and mature leaves of barley after $(\mathrm{Cd}+\mathrm{Cr})$ treatment.

$\mathrm{PT}=$ Partially tolerant; NT= Non-tolerant; Con. = Concentration; RSD= Relative Standard Deviation; S/R=Ratio of Shoot and root.

Table 3. Accumulation $\left(\mu \mathrm{g} \mathrm{g}{ }^{-1}\right.$ dry weight) of cadmium in roots and mature leaves of barley after $(\mathrm{Cd}+\mathrm{Cr})$ treatment.

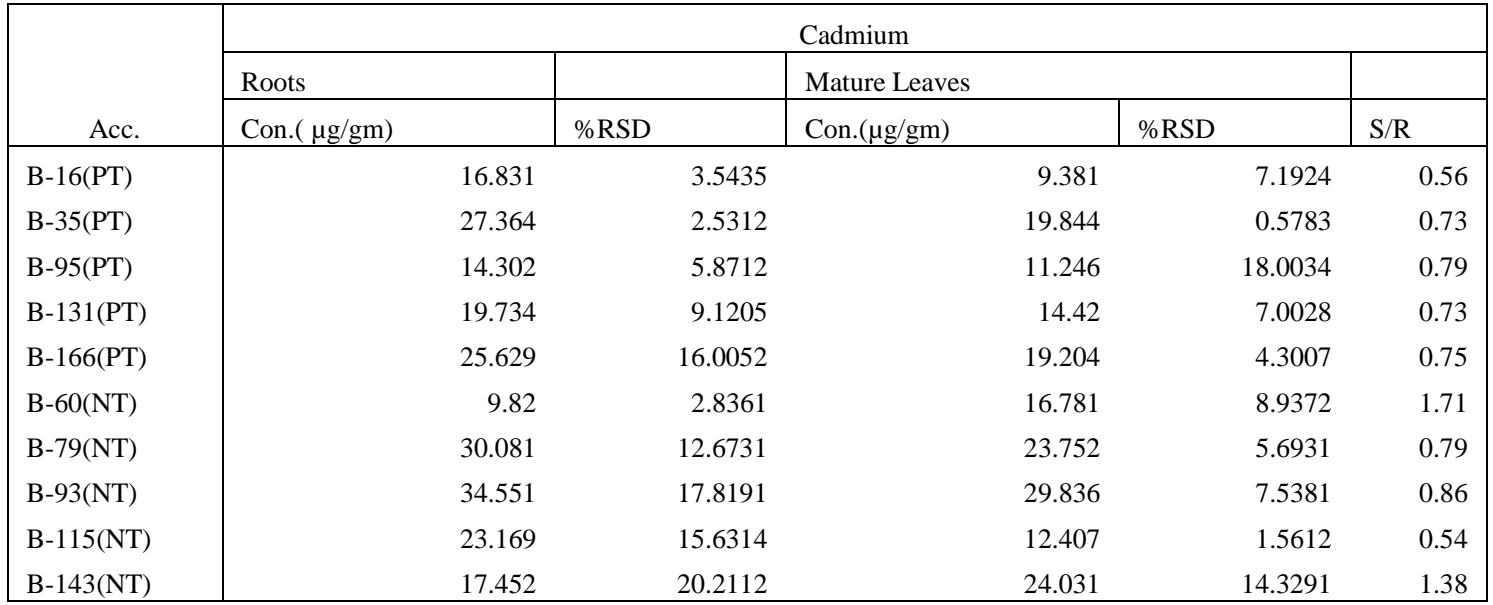

$\mathrm{PT}=$ Partially tolerant; NT = Non-tolerant Con. = Concentration; RSD= Relative Standard Deviation; S/R=Ratio of shoot and root. 


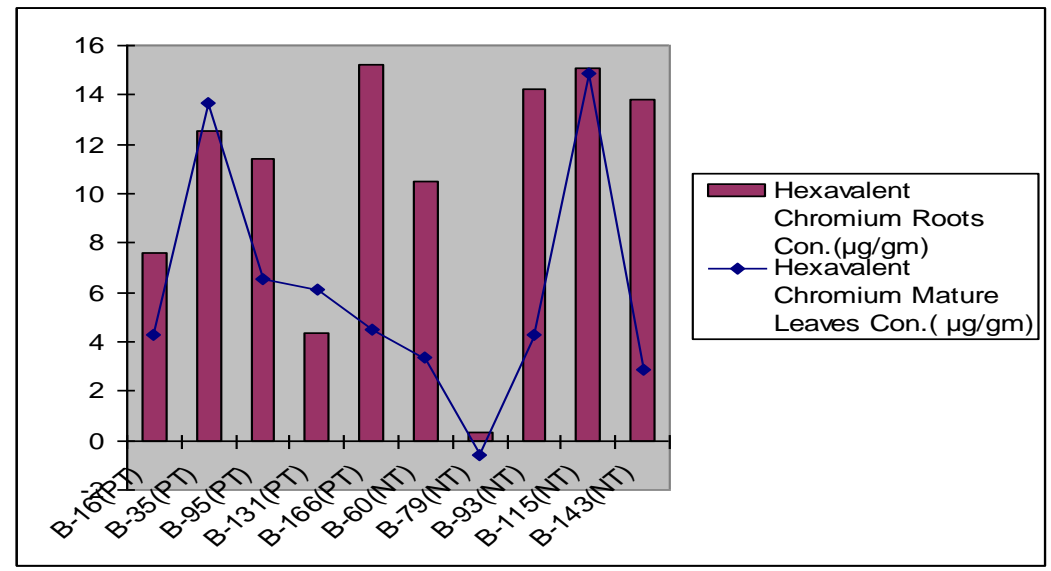

Fig.1 Concentration $\left(\mu \mathrm{g} / \mathrm{g}^{-1}\right.$ dry weight) of hexavalent chromium in roots and mature leaves of barley.

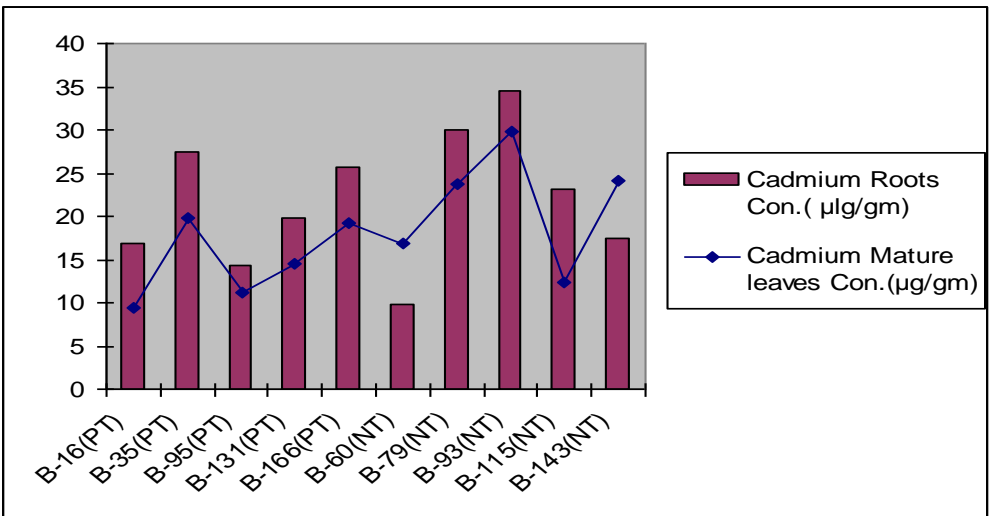

Fig. 2 Concentration $\left(\mu \mathrm{g} / \mathrm{g}^{-1}\right.$ dry weight $)$ of cadmium in roots and mature leaves of barley.

Minimum accumulated concentration of hexavalent chromium was $0.35 \mu \mathrm{g} \mathrm{g}^{-1}$ in roots of B-78 (NT) and maximum was $15.19 \mu \mathrm{g} / \mathrm{g}^{-1}$ in roots of B-166 (PT) while in mature leaves minimum accumulated concentration was $0.00 \mu \mathrm{g} / \mathrm{g}^{-1}$ in B-79 and maximum concentration was $14.85 \mu \mathrm{g} / \mathrm{g}^{-1}$ in B-115 (NT). Ratio of accumulated hexavalent chromium in mature leave to root (Translocation factor) was $>1$ in B-35(PT), B131(PT) since mature leaves accumulated higher amount of chromium in comparison to root, and $<1$ in $\mathrm{B}$ 16(PT), B-95(PT), B-166(PT) 60-(NT), B-79(NT), B-93(NT), B-115(NT) and B-131(PT) because of reverse situation. Minimum accumulated concentration of cadmium in roots was $9.82 \mu \mathrm{g} / \mathrm{g}^{-1}$ in B-60(NT) and maximum was $34.55 \mu \mathrm{g} / \mathrm{g}^{-1}$ in root of B-93(NT), while in mature leaves minimum accumulated concentration of cadmium was $9.38 \mu \mathrm{g} / \mathrm{g}^{-1}$ in B-16(PT) while maximum was $29.84 \mu \mathrm{g} / \mathrm{g}^{-1}$ in B-93(NT). In barley ratio of accumulated cadmium in mature leaves to root (Translocation factor) was $>1$ in B-60-(NT), B-143(NT) because of higher cadmium accumulation in leaves as compared to root and <1 in B-16(PT), B-35(PT), B-79(NT), B-93(NT), B95(PT), B-115(NT), B-131(PT), and B-166(PT), reveals higher cadmium accumulation in root over those of leaves.

In general, cadmium could be accumulated in higher amount over that of hexavalent chromium in roots as well as mature leaves.

\section{Discussion}

The concept of using plants to clean up contaminated environment is not new, about 300 years ago; plants were first proposed for use in the treatment of waste water (Hartman, 1975). At the end of $19^{\text {th }}$ century, Thlaspi caerulescens and Viola calaminaria were the first plant species documented to accumulate high levels of metals in leaves (Baumann, 1885). Plants able to accumulate upto 1\% nickel in shoots were reported by Minguzzi and Vergnano (1948) and Rascio (1977), reported high zinc accumulation in shoots of Thlaspi caerulescens. Brassica species now-a-days have received much attention for their metal accumulation capability. Studies carried with different varieties of B. juncea (Indian mustard) have shown that these plants were able to take up and concentrate toxic metal to a level up to several percent of their dried shoot biomass. Dushenkov et al. (1995) identified certain varieties of sunflower (Helianthus annuus) as being the most efficient plants for rhizofilteration. 
Perusal of present set of data on cadmium and hexavalent chromium accumulation indicated that barley accessions could accumulate cadmium and hexavalent chromium in the roots as well as in mature leaves. In most accessions the concentration of both heavy metals was higher in the roots as compared to the mature leaves. The use of roots of terrestrial plants to remove organics or heavy metals from aqueous solutions may provide the foundation for a novel water treatment technology. The use of roots of terrestrial plants to remove organics or heavy metals from aqueous solutions may provide the foundation for a novel water treatment technology. Conceivably, this method may be applicable to the treatment of surface and ground water and industrial effluents to reduce the burden of contaminants. Plants that enhance organic degradation or accumulate toxic metals can be grown and harvested economically leaving the soil or water with a greatly reduced level of toxic chemical contamination.

Translocation Factor (TF) was described as ratio of heavy metals in plant shoot to that in plant root (Cui et al., 2007; Li et al., 2007). TF >1 had been used to evaluate the potential of plant species for phytoextraction and phytostabilization (Yoon et al., 2006; Li et al., 2007). Accumulation of cadmium and hexavalent chromium in mature leaves indicated that in some of the accessions, cadmium and hexavalent chromium could be translocated from roots to shoots.

Since, the accessions of barley differed from each other in their genotypes; these findings indicated that not only the accumulation of cadmium and hexavalent chromium but also its translocation from root to shoot was genotype dependent. Green plants can be compared with the 'solar driven pumping and filtering systems' that have 'measurable loading, degrading and fouling' capacity. Roots may similarly be described as 'exploratory, liquid-phase extractor' that can find, alter and/or translocate elements and compounds against large chemical gradients (Cunningham and Berti, 1993).

High metal accumulation may be attributed to well develop detoxification mechanism based on sequestration of heavy metal ions in vacuoles, by binding them on appropriate ligands such as organic acids, proteins and peptides in the presence of enzymes that can function at high level of metalicions (Cui et al., 2007) and metal exclusion strategies of plant species (Ghosh \& Singh, 2005). The elevated concentration of heavy metals in roots and low translocation in above ground parts $(\mathrm{TF}<1)$ indicated their suitability for phytostabilisation.

The author acknowledge to the DST for providing INSPIRE fellowship.

\section{References}

[1]. Baker A J M, 1981. Accumulators and excluders strategies in the response of plants to heavy metals [J]. J. Plant Nutr. 3(1-4): 643654.

[2]. Baker A J M, Brooks R R, 1989. Terrestrial higher plants which hyperaccumulate metallic elements. A review of their distribution, ecology and phytochemistry [J]. Biorecovery, 1: 81-126.

[3]. Baker A J M, McGrath S P, Reeves R D et al., 2000. Metal hyperaccumulator plants: A review of ecology and physiology of a biological resource for phytoremediation of metal polluted soils [M]. In: "Phytoremediation of Contaminated Soil and Water". N. Terry and others, Boca Raton (ed), 129-58.

[4]. Baumann A, 1885. Das Verhalten von Zinksatzen gegen Pflanzen und im Boden[M]. Landwirtsch. Vers.-Statn. 31: 1-53.

[5]. Chunilall V, Kindness A, Jonnalagadda S B, 2005. Heavy metal uptake by two edible Amaranthus herbs grown on soils contaminated with Lead, Mercury, Cadmium and Nickel [J]. J. Environ. Sci. Health, 40: 375-384.

[6]. Cui S, Zhou Q, Chao L, 2007. Potential hyper-accumulation of $\mathrm{Pb}, \mathrm{Zn}, \mathrm{Cu}$ and $\mathrm{Cd}$ in endurant plants distributed in an old smeltery, northeast China [J]. Environmental Geology, 51: 1043-1048.

[7]. Cunningham S D, Berti W R, 1993. Remediation of contaminated soils with green plants, an overview[J] . In Vitro Cell. Dev. Biol, 29: 207-212.

[8]. Dushenkov V, Nanda Kumar P B A, Motto H et al., 1995. Rhizofiltration: The use of plants to remove heavy metals from aqueous streams [J]. Environ. Sci. Technol, 29: 1239-1244.

[9]. Ghosh M, Singh S P, 2005. A review on phytoremediation of heavy metals and utilization of its byproducts [J]. Applied Ecology and Environmental Research, 3: 1-18.

[10]. Haferburg G, Kothe E, 2010. Metallomics: lesssons for mettalliferous soil remediation[J] . Appl. Microbiol. Biotechnol, 87: 12711280.

[11]. Hartman W J J, 1975. An evaluation of land treatment of municipal wastewater and physical silting of facility installations [M]. Washington DC, US, Department of Army.

[12]. La'zaro, D J, Kiddb P S, Martýnneza C M T, 2006. A phytogeochemical study of the Tra's-os- Montes region (NE Portugal): Possible species for plant-based soil remediation technologies [ J]. Science of the Total Environment, 354: 265- 277.

[13]. Li M S, Luo Y P, ZY Su, 2007. Heavy metal concentrations in soils and plant accumulation in a restored manganese mineland in Guangxi, South China [J]. Environmental Pollution, 147: 168-175.

[14]. McGrath S W, Zhao F J, Lombi E, 2001. Plant and rhizosphere processes involved in phtoremediation of metalcontaminated soils [J]. Plant and Soil, 232(1-2): 207-214.

[15]. Minguzzi C, Vergnano O, 1948. II contento di nichel nelli ceneri di Alyssum bertlonii Desv[J] . Atti delia Societa Toscana di Science Naturali, Mem Ser A, 55: 49-77.

[16]. Rascio W, 1977. Metal accumulation by some plants growing on Zn mine deposits [J]. Oikos ,29: 250-253.

[17]. Reeves R D, Baker A J M, 2000. Metal accumulating plants. In: "Phytoremediation of Toxic Metals: using Plants to clean up the Environment", I. Raskin and B.D. Ensley, John Wiley and Sons, (ed) Inc, Toronto, Canada, 303

[18]. Yoon J, Cao X, Zhou Q, Ma L Q, 2006. Accumulation of $\mathrm{Pb}, \mathrm{Cu}$, and $\mathrm{Zn}$ in native plants growing on a contaminated Florida site [J]. Science of the Total Environment, 368: 456-464. 